\title{
GNG2 Gene
}

National Cancer Institute

\section{Source}

National Cancer Institute. GNG2 Gene. NCI Thesaurus. Code C114328.

This gene plays a role in GT Pase-dependent signaling. 